The Impact of Using Activities Based on the Montessori Approach in Science in the Academic Achievement of Fourth Grade Students

\title{
Azza Alburaidi
}

Science Teacher, Ministry of Education, Oman

\section{Abdullah Ambusaidi}

Prof., College of Education, Sultan Qaboos University, Oman, ambusaid@squ.edu.om

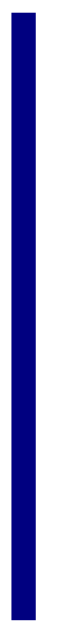

This study investigated the effect of using activities based on the Montessori approach in science academic achievement of the fourth grade students. A quasiexperimental design was used wherein the students were equally divided into two groups: the experimental and the control group. Both groups consisted of 31 students. To achieve the aim of the study, Montessori Hall has been set up with six dimensions, and each corner has several shelves comprised different materials used for conducting the science activities. In addition, a teacher guide was prepared to be used by the teacher to implement the Montessori approach for the experimental group. Finally, an achievement test that consisted of seven multiple choice questions (MCQs) and five short answer questions was constructed and administered to both study groups. The results of the study indicated that there were statistically significant differences at the level of significance $(P \leq 0.05)$ between the mean values of the experimental and the control groups in the academic achievement in favor of the experimental group. In light of the study results, the study recommends holding training workshops for teachers on how to use the Montessori approach in teaching science classes.

Keywords: Montessori Approach, science, academic achievement, 4th grade, teaching, learning

\section{INTRODUCTION}

Educational activities are one of the powerful strategies that teachers can use with their students to teach different subjects, especially in the primary and preschools levels. The diversity of activities used by teachers indicates their importance in providing students with a variety of skills that sharpen various aspects of their behavior. Besides that, concert-based activities develop students' sensorial abilities and foster acquiring diverse knowledge and skills profoundly. Moreover, limiting learning activities in science keep

Citation: Alburaidi, A., \& Ambusaidi, A. (2019). The Impact of Using Activities Based on the Montessori Approach in Science in the Academic Achievement of Fourth Grade Students. International Journal of Instruction, 12(2), 695-708. https://doi.org/10.29333/iji.2019.12244a 
the students from using their different senses, and the lesser they are able to connect themselves to the surrounding environment, the lesser their acquisition of scientific knowledge. This may lead to low students' academic achievement and difficulties in the acquisition of thinking skills (Ambusaidi \& Al Balushi, 2015).

One of the primary objectives of science, especially in the first cycle (Grades 1-4), is to deal with the senses, which can be achieved through the diversity of activities. One way to do this is to adopt an approach that targets the students' different senses. Montessori approach is one of them, and it deals with educating children by means of the senses. Hence, it can be described as an educational system based on the use of the senses, where the interaction is occurred between teacher, child, and environment (Isaacs, 2015).

Gross (1986) pointed out that the Montessori approach was one of the early intervention approaches for children. The idea was attributed to an Italian physician named Maria Montessori, who in turn was influenced by the ideas of other educators. Montessori felt that children have an intellectual structure that gradually grows with them. This approach has been essential in both education and psychology (Dogru, 2015; Murray, 2012). In the education side, the importance of the Montessori approach has evolved from its critical, creative, and sensorial thinking development in children, as well as the development of a child's senses through dealing with sensorial materials. It also has an effect on developing students' language, intellectual, and problem-solving abilities. In addition, it also has effects on children's personality development, confidence, and selfesteem. This is because the child in the Montessori's environment is free to move in the class, to choose his material, to work as long as he wants and where he wants (Barbieru, 2016).

A Montessori school's environment is different from the environment in mainstream schools (Lillard, 1972; Montessori, 1995a; Hiles, 2015; Hainstock, 1986). It is an attractive and exciting environment for children because of its ready-made educational activities that reflect all aspects of child development and meet the needs and tendencies of children. Montessori has developed learning methods and activities that are commensurate with the characteristics of each stage of human development from birth up to 24 years (Onail, 2006; Montessori, 1985; Montessori, 1976).

A Montessori teacher is distinguished from a teacher in the other prevalent approaches with a role that is different from other classrooms. His/her role is to observe children and monitor their behavior without interfering in the work of their activities (Sackett, 2016; Malam, 2004; Barbieru, 2016). This approach results in students being enthusiastic and motivated toward learning. Ahmed's study (2004) indicated that stimulating students' motivation before implementing educational activities encouraged students to discover and learn, and has raised academic achievement. The role of the teacher is not only to provide activities, but also to examine the educational material to ensure its safety, to replace the damaged ones, and to inspect and recycle all consumables such as plastics, woods and some metal made materials (Aucoin, 2015; Feez, 2010).

Hanson's study (2009) showed that the diversity in the teaching methods of teachers by introducing the Montessori approach increased the enthusiasm and performance of learners. The uniqueness of learning helped children to work individually and 
collectively. Murray's (2008) study about the teaching and learning of students using the Montessori approach as viewed by people of United States (US) found that they had high awareness of the term "Montessori," although knowledge of the details of Montessori way of teaching and learning was low. Despite of this, the study found that most US residents believed that Montessori education plays a clear role in the academic growth of children.

A Montessori environment has been designed to attract a child's attention and interest and encourage movement. This has led to an increase in academic achievement. Hobbs (2008) showed that the academic achievement in reading and mathematics of Montessori schools was higher than students' achievements in non-Montessori schools. This was confirmed by Mallett (2013), whose study found that the academic achievement of Montessori students from the first and second grades is similar to the academic achievement of non-Montessori students from the fourth and fifth grades. However, this result is not supported by other previous studies. For example, the study by Salazar (2013) showed no difference in the results of the achievement between Montessori students and students who studied mathematics and reading in a prevalent method of teaching.

Keppler (2009) asserted the importance of punitive play in the Montessori classes. He encouraged teachers to practice this type of play in order to meet their students' needs. Bahtheg (2010) has demonstrated that the use of sensorial or concert materials such as toys, has improved the problem-solving skills of children. Sullivan-Smith (2008) have confirmed that the Montessori program is more effective in developing sensorial skills in preschool autistic children compared with the mainstream method in education.

Furthermore, Metwally (2015) pointed out the importance of the Montessori approach to develop practical life skills and environmental care skills among kindergarten children. Woodsklar and Caitlin's (2007) study found that the Montessori approach developed the independence skills of autistic children. Moreover, Ahmed (2014) revealed that the strengths of the Montessori approach; because it focused on learning that centered on learner and teacher's role is to facilitate the learning process and only intervene on children upon their needs The study also focused on the basic principles of Montessori education, which are in line with the current curriculum in Cairo schools. This complies with the current study that the Montessori approach works to develop independence sensorial skills of children and improve problem-solving skills, which lead to improve their academic achievement.

Lillard's study (2012) confirmed that the use of silent game play, a Montessori approach, led to a significant improvement in children's ability to relax. The results of Lillard's study supported the results of Chisnall's (2011) study, which found that using the Montessori approach improved the comprehensive growth of children in a normal classroom.

\section{Teaching Science in Omani Grades 1-4:}

The Omani education system consists of 12 years of schooling divided into three stages: grades 1-4, grades 5-10, and grades 11-12. In grades 1-4, both sexes (male and female) 
are studying together in one class. In these grades, all teachers, regardless of their subjects, are female. Science is one of the core subjects in these grades.

The main aim of teaching science in basic education (primary schools) (grades 1-4) schools is to provide the students with knowledge, attitudes, and skills to become literate citizens. The scientific information in science textbooks are limited which means that science teachers should conduct research to enrich his/her information about the science concepts. In addition, grades 1-4 schools lack the necessary facilities such as laboratories. Hence, science teachers should design the scientific activities and supporting materials by themselves, causing difficulties to some. The mode of teaching science in basic education (grades 1-4) schools in Oman focuses on the nature of science and the science processes. Science teachers are required to teach and train students on how to use these processes.

The number of lessons allocated to science in grades 1-3 are three per week, but five in grade 4. It seems that these lessons are enough to cover all the content and assess students in achieving the outcomes of each topic.

In the year 2017/2018 academic year, the Ministry of Education decided to use the Cambridge curriculum for science. The textbooks and teachers' manual are all translated into Arabic and adopted the Omani environment and culture. All grades 1-4 teachers are trained on how to teach science using these books. These books are for inquiry-based learning, which means teachers should change their traditional ways of teaching, and teach science by concentrating more on the activities, making the students the center of these teachings.

In this reform of science teaching, students are provided with student's book and activity book to be used while study science. . Teachers work as facilitators for students to learn science effectively and meaningfully. It has been hoped that these changes will improve teaching of science in Omani schools, although time is needed to see these changes in the field.

\section{RESEARCH QUESTIONS}

The current study seeks to investigate the effect of the Montessori approach in the 4th grade science classroom in raising up the academic achievement. The researchers assume that using diverse activities based on the Montessori approach may help these students to have a better achievement in the science subject. However, studies related to the application of the Montessori approach in teaching science in Oman are lacking. The researchers hope that this study will give other researchers the motivation to conduct more research in this field. The researchers expect that this study will benefit the curriculum designers, educational supervisors, and teaching staff, especially science teachers. Therefore, the study aims to answer the following research question:

What is the impact of using activities based on the Montessori Approach in the achievement of science for fourth grade students? 


\section{METHOD}

\section{Study Sample}

The number of participants was 62 4th grade students selected from two basic education schools (grades 1-4). They were divided into two groups. The experimental group consisted of 31 students, who were taught science by the Montessori approach. The control group also consisted of 31 students who were taught science by the conventional methods of teaching, usually based on activities conducted by teachers requiring less participation from students. The science content covered was the same for both groups except the difference in the way of delivering it to students. The lesson duration in both groups was 45 minutes, which is the same allocated to each lesson in Oman education system. However, for the experimental group students and to give them enough time to practice the activities prepared, teaching is done by combining two consecutive lessons.

\section{The Study Design}

The study followed quasi- experimental design (Figure 1).

Figure 1

$\begin{array}{cccc}\text { Experimental } & \mathrm{O} 1 & \mathrm{X} & \mathrm{O} 2 \\ & -\mathrm{O}^{-} & \\ \text {Control } & \mathrm{O} 3 & & \mathrm{O} 4\end{array}$

The study design

The independent variable of the current study is the teaching methods which has two levels; using the Montessori approach with the experimental group and the used of conventional method with the control group. The dependent variable is $4^{\text {th }}$ grade achievement of science in three levels of learning (knowledge and understanding, application and reasoning). The researchers tried to control all variables that may affect the internal validity of the research design. These included the qualifications and experiences of both experimental and control groups' teachers, the age of students in both groups and the science content taught to both groups.

\section{Teacher's Guide:}

The Teacher's Guide was designed to be used for teaching using the Montessori approach. It includes lesson plans and activities on specific units such as electricity, movement, and heat, which exists in the science curriculum. The guide included a list of the educational outcomes expected for each lesson. The researchers chose the unit on "electricity, movement and temperature" because of its adequacy with activities that can be implemented with the Montessori approach.

The preparation of the guide has gone through several stages, including access to previous studies, such as Ahmad (2004); Ambusaidi and Al- Balushi (2006); Khataibah (2005); Bati and Kaptan (2010); and Hason (2013), and different websites from the internet concerning teaching through the Montessori approach. The guide was then given to eight experts for revision and improvement. According to their comments and suggestions, the guide was developed and ready to be implemented. 


\section{Montessori Hall:}

In order to implement the Montessori approach in teaching 4th grade students, one room in a target school was allocated for the researchers to redesign and furnish. The hall consisted of six corners which are:

1) Exploration Corner: includes tools and materials used in scientific experiments such as wires, lamps, batteries, etc.

2) Sensorial Materials Corner: includes tangible material such as clay for shaping, readymade educational tools such as circuit boards, and other tools as required. 3) Creativity Corner: includes A4 paper, colored paper, art paper, pencil crayons, rulers, and drawing tools.

4) Computer Corner: includes laptop and projector to watch videos and tutorials related to the lesson.

5) Scientific library Corner: includes picture cards, books, magazines, newspapers, and scientific encyclopedias.

6) Writing Corner: includes classroom activities related to study unit "Electricity and Heat", assignments, some references suitable to grade 4 students, and student notebooks.

Students worked in each corner depending on the task given to them. Figures 2 and 3 show some pictures of the hall with the students working.
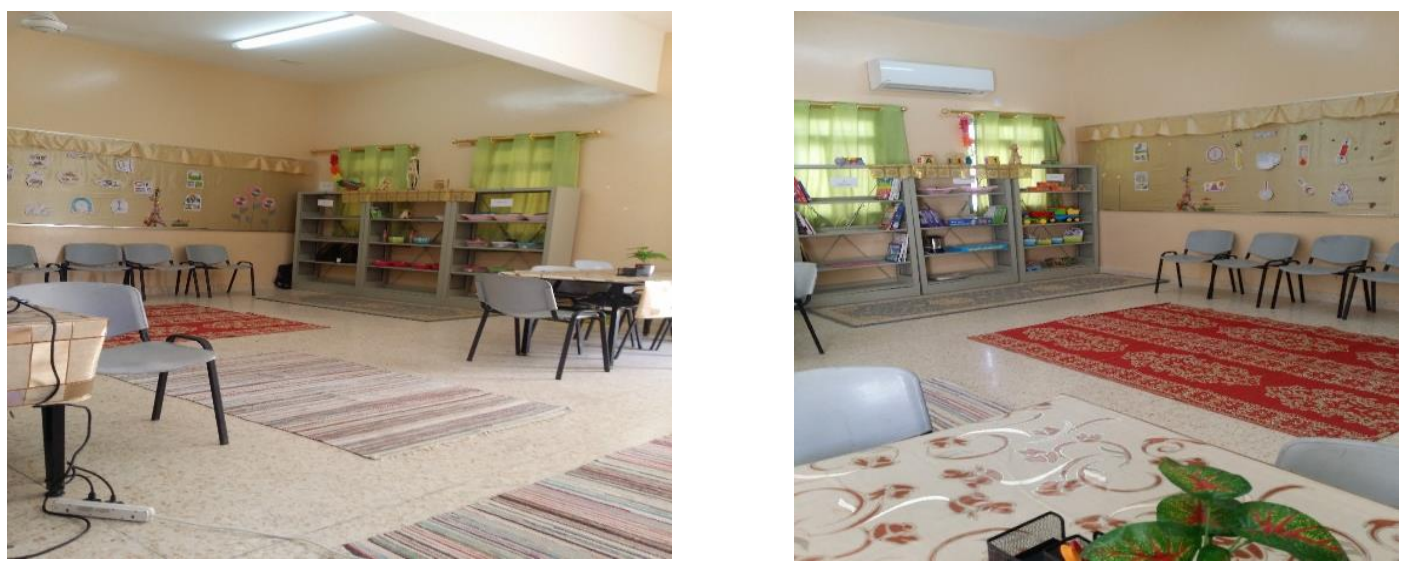

Figure 2

The Montessori Hall 

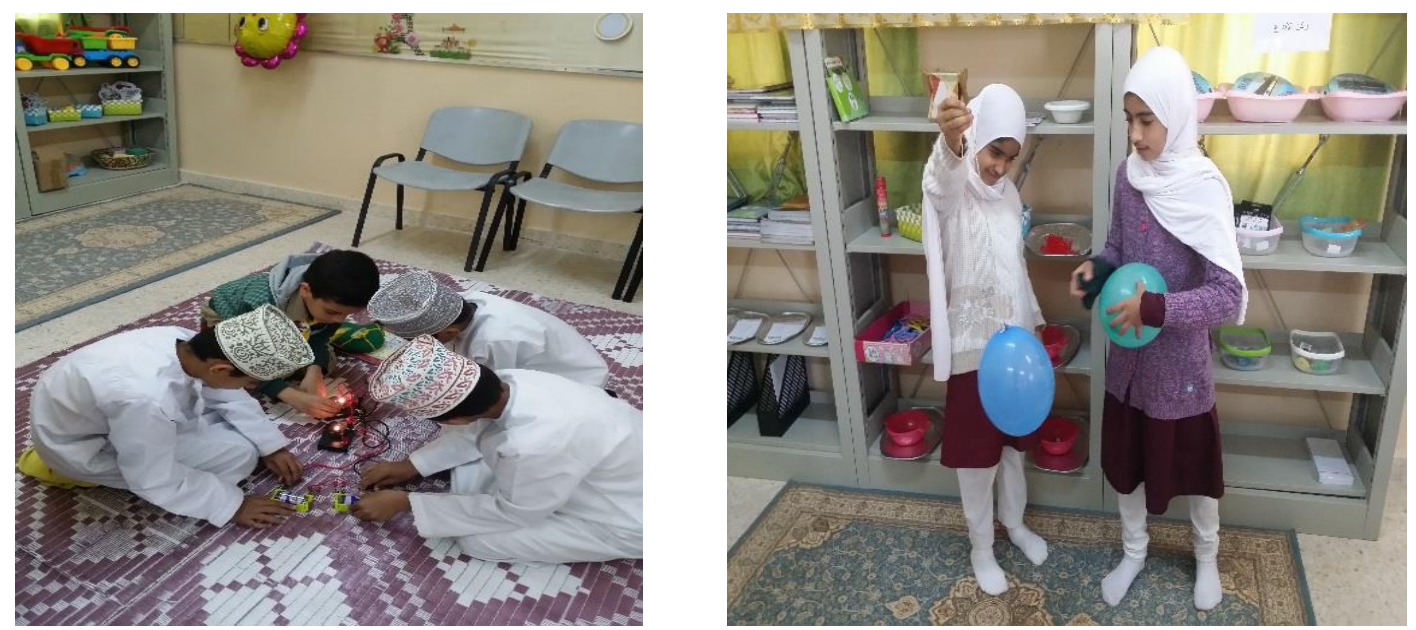

Figure 3

Students' working with activities in the Montessori Hall

\section{Study Tool:}

An achievement test was constructed to study the effect of the use of the Montessori approach on the achievement of 4th grade students in the chosen unit of (electricity, movement, and heat). It had both MCQs and short answer questions. The first step in preparing the test was making the table of specifications, which is a requirement of the Ministry of Education (Ministry of Education, 2017) and should include the following three levels: Knowledge and understanding (30\%), application $(40 \%)$, and reasoning $(30 \%)$. The test was composed of seven MCQs (four alternatives) and five short answer questions with sub-questions in some of them. Some of these questions based on drawing and used pictures, which is more suitable to test students at this grade. In order to verify the validity of the test, it was handed to 11 experts from the Sultan Qaboos University and the Ministry of Education. In light of their revisions and suggestions, the necessary amendments were made to show the test in its final form. To check the reliability of the test, it was applied on 28 fourth $\left(4^{\text {th }}\right)$ grade students, selected from another school that was not included in the study sample. The internal consistency method was used by calculated the Alpha Cronbach. The value of the Alpha coefficient was 0.91, which showed a strong indicator of test reliability. In addition, the difficulty index for each question in the test was range between $0.70-0.85$ and the discrimination index was range between $0.55-0.75$.

\section{Pretest of the Study Tool:}

In order to determine equivalence of the two groups before the intervention (teaching experimental group with Montessori approach) occurred, the achievement test was administered to both groups and the results are presented in Table 1 below. 
Table 1

Mean values, SD of pretest of both groups

\begin{tabular}{llll}
\hline Level of Knowledge & Group & Mean Value & SD \\
\hline Knowledge and & Experimental & 1.45 & .637 \\
\cline { 2 - 4 } Understanding & Control & 1.23 & .884 \\
\hline \multirow{2}{*}{ Application } & Experimental & 1.58 & .672 \\
\cline { 2 - 4 } & Control & 0.77 & 1.087 \\
\hline \multirow{2}{*}{ Reasoning } & Experimental & 1.68 & 1.249 \\
\cline { 2 - 4 } & Control & 1.61 & 1.520 \\
\hline \multirow{2}{*}{ Total } & Experimental & 4.71 & 1.80 \\
\cline { 2 - 4 } & Control & 3.58 & 2.45 \\
\hline
\end{tabular}

The results in Table 1 show that there are differences in the mean values between students of experimental group and students of control group in all three levels of learning and the test as a whole. To determine if these differences are statistically significant or not, the first stem of MANOVA is calculating the Wilks' Lambda. The value of Wilks' Lambda is 0.742 which is significant at 0.05 level. The second step in MANOVA is to find out which component of the test has a significant difference. The results of calculating MANOVA are presented in Table 2.

Table 2

MANOVA Results of pretest.

\begin{tabular}{|c|c|c|c|c|c|c|c|}
\hline Sources & $\begin{array}{l}\text { Level of } \\
\text { Knowledge }\end{array}$ & $\begin{array}{l}\text { Type III Sum of } \\
\text { Squares }\end{array}$ & df & $\begin{array}{l}\text { Mean } \\
\text { Square }\end{array}$ & F & Sig. & $\begin{array}{l}\text { Partial Eta } \\
\text { Squared }\end{array}$ \\
\hline \multirow[t]{4}{*}{ Group } & $\begin{array}{l}\text { Knowledge and } \\
\text { Understanding }\end{array}$ & .790 & 1 & .790 & 1.332 & .253 & .022 \\
\hline & Application & 10.081 & 1 & 10.081 & 12.352 & $.001 *$ & .171 \\
\hline & Reasoning & .065 & 1 & .065 & .033 & .856 & .001 \\
\hline & Whole Test & 19.758 & 1 & 19.758 & 4.288 & $.043 *$ & .067 \\
\hline \multirow[t]{4}{*}{ Error } & $\begin{array}{l}\text { Knowledge and } \\
\text { Understanding }\end{array}$ & 35.597 & 60 & .593 & & & \\
\hline & Application & 48.968 & 60 & .816 & & & \\
\hline & Reasoning & 116.129 & 60 & 1.935 & & & \\
\hline & Whole Test & 276.435 & 60 & 4.607 & & & \\
\hline \multirow[t]{4}{*}{ Total } & $\begin{array}{l}\text { Knowledge and } \\
\text { Understanding }\end{array}$ & 147.500 & 62 & & & & \\
\hline & Application & 145.000 & 62 & & & & \\
\hline & Reasoning & 284.000 & 62 & & & & \\
\hline & Whole Test & 1361.500 & 62 & & & & \\
\hline
\end{tabular}

The results in Table 2 show that there are significant differences between the mean values of the experimental group and control group in science achievement prior to applying the intervention in application level and in the test as whole. However, there are no significant differences in the knowledge and understanding and reasoning levels. Because the two groups are not equivalent in the test as a whole, Multivariate Analysis of Covariance (MACNOVA) was used in the posttest analysis. 


\section{Data Analyses}

To answer the research question, mean values, standard deviations and MANOVA were used for pretest of the academic achievement test. Because there was a statistically significant differences in the mean values of the academic achievement test and one level of knowledge (application) between experimental and control groups, Multivariate Analysis of Covariance of covariance (MANCOVA) was used in the posttest.

\section{FINDINGS}

To answer the research question: "What is the effect of using Montessori based activities to $4^{\text {th }}$ grade students' science achievement?" the achievement test was administered to both groups after the intervention. Multivariate Analysis of Covariance (MANCOVA) was used to determine if there are any significant differences in the mean scores. Table 3 shows the adjust mean values and standard error for the three levels of knowledge and the test as a whole.

Table 3

Adjusted Mean values and Standard Error of students' achievement in the posttest

\begin{tabular}{lllll}
\hline Level of Knowledge & Group & $\begin{array}{l}\text { Max. Score of } \\
\text { Each Level }\end{array}$ & $\begin{array}{l}\text { Adjusted Mean } \\
\text { Value }\end{array}$ & St.Error \\
\hline Knowledge and & Experimental & 6 & 5.29 & .175 \\
\cline { 2 - 5 } Understanding & Control & 6 & 2.40 & .175 \\
\hline \multirow{2}{*}{ Application } & Experimental & 8 & 5.99 & .316 \\
\cline { 2 - 5 } & Control & 8 & 2.40 & .316 \\
\hline \multirow{2}{*}{ Reasoning } & Experimental & 6 & 4.92 & .198 \\
\cline { 2 - 5 } & Control & 6 & 1.56 & .198 \\
\hline Total & Experimental & 20 & 16.2 & .573 \\
\cline { 2 - 5 } & Control & 20 & 6.36 & .573 \\
\hline
\end{tabular}

Table 3 shows that the adjusted mean values of the experimental group of each level and for the whole test is better compared with the control group. To find out if these differences are statistically significance or not, MANCOVA was used and the results presented in Table 4.

Table 4

MANCOVA Results of posttest.

\begin{tabular}{|c|c|c|c|c|c|c|c|}
\hline Sources & $\begin{array}{l}\text { Level of } \\
\text { Knowledge }\end{array}$ & $\begin{array}{l}\text { Type III Sum } \\
\text { of Squares }\end{array}$ & df & Mean Square & $\mathrm{F}$ & Sig. & $\begin{array}{l}\text { Partial Eta } \\
\text { Squared }\end{array}$ \\
\hline \multirow[t]{4}{*}{ Pre-Test } & $\begin{array}{l}\text { Knowledge and } \\
\text { Understanding }\end{array}$ & .790 & 1 & .790 & 1.332 & .253 & .285 \\
\hline & Application & 10.081 & 1 & 10.081 & 12.352 & $.001^{*}$ & .174 \\
\hline & Reasoning & .065 & 1 & .065 & .033 & .856 & .274 \\
\hline & Whole Test & 19.758 & 1 & 19.758 & 4.288 & $.043^{*}$ & .302 \\
\hline \multirow[t]{4}{*}{ Group } & $\begin{array}{l}\text { Knowledge and } \\
\text { Understanding }\end{array}$ & 121.184 & 1 & 121.184 & 132.288 & $.001 *$ & .692 \\
\hline & Application & 186.070 & 1 & 186.070 & 62.345 & $.001 *$ & .514 \\
\hline & Reasoning & 163.599 & 1 & 163.599 & 139.914 & $.001^{*}$ & .703 \\
\hline & Whole Test & 1401.732 & 1 & 1401.732 & 142.520 & $.001 *$ & .707 \\
\hline \multirow[t]{3}{*}{ Error } & $\begin{array}{l}\text { Knowledge and } \\
\text { Understanding }\end{array}$ & 54.048 & 59 & .916 & & & \\
\hline & Application & 176.087 & 59 & 2.985 & & & \\
\hline & Reasoning & 68.988 & 59 & 1.169 & & & \\
\hline
\end{tabular}




\begin{tabular}{lllll}
\hline & Whole Test & 580.286 & 59 & 9.835 \\
\hline Total & Knowledge and & 1152.750 & 62 & \\
\cline { 2 - 5 } & Understanding & 1551.500 & 62 \\
\cline { 2 - 4 } & Application & 660.000 & 62 \\
\cline { 2 - 4 } & Reasoning & 10571.250 & 62 & \\
\cline { 2 - 4 }$* 0 \leq 0.05$ & Whole Test & &
\end{tabular}

Table 4 shows that there is a statistically significant difference in the adjusted mean values of the test as a whole and in the three levels of knowledge, in favor of the experimental group. The effect size of using the Montessori approach in the three levels of learning and for whole test is high as the values of $\eta 2$ in the three levels of knowledge and the test as a whole are greater than 0.50 (Cohen, 1988). This means that the Montessori approach has big effect in raising the science academic achievement of the $4^{\text {th }}$ grade students.

\section{DISCUSSION}

This approach has shown that it motivated students because of the activists that were set up in each corner of the Montessori Hall. For example, one creative activity asked students to color drawings related to science phenomena such as the natural sources of heat, the heat generated from electricity or the heat produced from fuel consumption. The materials in a Montessori hall were presented to students in a natural and orderly manner, and students selected the materials they like to use without interfered from teacher (Walsh \& Petty, 2007).

This type of activity drove the students' learning from shallow to meaningful. In addition, the activities that were based on Information and Communication Technology (ICT) such as Physic Crocodile Programme, students' enriched the learning of science. It helped the teacher enhance students' motivation, which positively affects students' learning (Rice, 2017).

In the Montessori Hall, the library has been activated. Students were asked to use this small library in one corner of the classroom for two purposes: searching information and improving students' reading skills. The library is equipped with different information sources such encyclopedias, books, and scientific journals. Reading in science is very important because it is itself, a scientific activity. Bulman (1982), as cited by Wellington and Osborne (2001), argued that if we wish to give our pupils a taste of being a real scientist, then reading should play an important part in our science lessons. In the Montessori classes, science teacher gives the opportunities to students to engage in communication and language by talking to each other, writing, and drawing pictures from books they like to read and that teachers read to them (Lillard, 1996).

In the Montessori classes, students are allowed to deal with sensorial or concert materials individually or in pairs and can be repeated many times until they reach the mastery level of learning. For example, in the current study, students were allowed to design electric circuits and measure the temperature of the body and water. They can do these activities several times until mastery is achieved. Dealing with sensorial or concert materials has led students to develop self-knowledge acquisition, confidence building, 
self-reliance, and understanding of the subject matter (La Malfa, Lassi, Bertelli, \& Pall, 2008).

The results of this study were consistent with the results of some previous studies such as Hanson's (2009) study, which emphasized that the diversity of teaching methods by teachers through the Montessori approach has increased the enthusiasm of learners and fostered their performance. The uniqueness of learning helped children to be able to work individually and collectively. This in turn helped them understand the concepts contained in the science curriculum and develop their individual abilities. Ahmed (2004) suggested that stimulating student motivation before implementing educational activities effectively encouraged them to discover and learn and raised their academic achievement. Mallett (2013) focused his study on comparing the academic achievements between Montessori students and non-Montessori students. The results of the study indicated that the achievement of Montessori students in the first and second grades was similar to that of the fourth and fifth grades students in non-Montessori schools. In line with the same results, Mcdurham's (2011) study found that there was a significant difference between the academic achievement of seventh and eighth graders who were enrolled in Montessori schools in Texas and their peers who were enrolled in public schools. The results of the study found that the Montessori students got higher literacy in science and mathematics compared with their peers in public schools.

However, not all previous studies reached the same results. The study by Lopata, Wallace, and Finn (2005) found that when comparing the academic achievement of primary school (4th grade) and middle school students (8th grade) in the Linguistic Arts and Mathematics tests, the Montessori approach had no effect. The achievements of the fourth grade Montessori students were not different from those in public schools in the linguistics, but they achieved better results in mathematics. Moreover, there were no statistical significance differences among Montessori students in grade eight in linguistics and mathematics compared to their peers from public schools.

\section{CONCLUSION AND IMPLICATIONS}

The present study investigated the impact of using activities based on the Montessori approach in science academic achievement of the $4^{\text {th }}$ grade students. The Montessori approach was found to be an effective approach to teach science in first-cycle grades (14 ), although most of the works done in this approach are at preschool levels. However, its principles can be adopted even at primary schools. There are some requirements that should be adopted to implement the Montessori approach at primary schools, but these requirements can be handled if the schools are willing to adopt the approach. One of the requirements of using the Montessori approach in primary education is to train teachers. The training can be in the form of workshops and in-field visits. Additionally, the science teachers, regardless of using the Montessori approach or not, should provide students with the opportunity to use tangible materials. This will help students grasp knowledge easily.

This is the first study that conducted the implementation of the Montessori approach in teaching science specifically and education in general in Oman. It has some limitations 
such as: it was implemented with a small number of students, and only used to assess its impact on students' achievement. Therefore, there is a need for more research in the investigation of the effect of the Montessori approach on developing students' critical thinking, creative thinking, problem solving, and the application of science processes skills.

\section{REFERENCES}

Ahmed, A. (2014). The effectiveness of an early intervention program using the Montessori activities to improve attention in autistic children. Childhood and Education Journal, 17, 353-399. (In Arabic)

Ahmed, N. (2004, July). The impact of the implicit evaluation strategy associated with the concept of the cycle of living organisms in the development of achievement, direction and processes of science for fourth graders. Paper presented at the eighth scientific conference Egyptian Association for Scientific Education, the missing dimensions in science curricula in the Arab world, Egypt. (In Arabic).

Ambusaidi, A. \& Al Balushi, S. (2015). Methods of Teaching Science: Concepts and Applications. Amman, Dar Al-Maserah for Publishing, Printing and Distribing. (In Arabic).

Ambusaidi, A. \& Al Balushi, K. (2006). The impact of problem-based learning strategy on the development of science operations among 10th grade students (first secondary) in biology in Sultanate of Oman. Gulf Message Journal, 109, 71- 102. (In Arabic).

Aucoin, D. (2015). Assessing collaboration: How teachers in Montessori public schools incorporate collaborative constructs for students in inclusion. Published Doctoral Dissertation, Northcentral University, USA.

Bahtheg, R. (2010). How the use of Montessori Sensorial Material supports Children's Creative Problem Solving in the Pre-school Classroom. Unpublished Doctoral Dissertation, University of Southampton. UK.

Bati, K. Ertürk, G \& Kaptan, F. (2010). The awareness levels of pre-school education teachers regarding science process skills, Procedia Social and Behavioral Sciences, 2, 1993-1999.

Barbieru, I. T. C. (2016). The Role of the Educator in a Montessori Classroom. Revista Romaneasca pentru Educatie Multidimensionala, 8(1), 107-123. doi: http://dx.doi.org/10.18662/rrem/2016.0801.07

Chisnall, N. (2011). Montessori education in Aotearo a New Zealand: A Framework for Peace and Social Justice. Unpublished Doctoral Dissertation, Auckland University of Technology. Aotearoa-New Zealand.

Cohen, J. (1988). Statistical Power Analysis for Behavioral Science (2ed). Hillsdale,N J: Lawrence.

Dogru, S. (2015). Efficacy of Montessori education in attention gathering skill of children. Academic Journals, 10(6), 733-738. 
Essa, E. (2017), Introduction to Early Childhood Education (translated by Abu Taleb, Taghreed, Ibrahim, Lina, Khondaneh and Ahlam). Amman, Dar Al Fikr Library. (In Arabic).

Feez,S. (2010). Montessori and Early Childhood. London, British Library Cataloguing.

Gross, M. (1986). Montessori's Concept of Personality. New York, Library of Congress Cataloging.

Hainstock, E. (1986). Essential Montessori. New York, New American Library.

Hanson, B. (2009). An exploratory study on the effectiveness of Montessori constructs and traditional teaching approach-logy as change agents to increase academic achievement of elementary black students. Unpublished Doctoral Dissertation, University of Capella, USA.

Hiles, E. (2015). Measuring Parent Perception and Understanding of Montessori Education at three Massachusetts Montessori Schools. Unpublished Doctoral Dissertation. Pepperdine University, USA.

Hobbs, A. (2008). Academic Achievement: Montessori and non-Montessori Private School Settings. Unpublished Doctoral Dissertation, University of Houston, USA.

Isaacs, B. (2015). Bringing the Montessori Approach to your Early Years Practice. Cornwall, Routledge Group.

Keppler, T. (2009). The Role of Play in Pre-School Montessori Classroom. Master Thesis, University of Alaska, USA.

Khatabiah, A. (2005). Science Education for All. Amman, Dar Al-Massiera for Publishing, Distribution and Classification. (In Arabic).

La Malfa, G.; Lassi, S.; Bertelli, M. \& Pall, S. (2008). Detecting attention- deficit/ hyperactivity disorder (ADHD) in adults with intellectual disability. Research in Developmental Disabilities, 29(2). 158-164.

Lillard. A. (2012). Preschool children's development in classic Montessori supplemented Montessori, and conventional programs. Journal of School Psychology, 50, 379-401.

Lillard, P. P. (1996). Montessori Today: A Comprehensive Approach to Education from Birth to Childhood. New York: Schocker Books.

Lillard, P. (1972). Montessori: a Modern Approach. New York, Schocken Books.

Lopata, C. Wallace, N. \& Finn, K. (2005). Comparison of academic achievement between Montessori and traditional education programs. Journal of Research in Childhood Education, 20(1), 5-13.

Malam, B. (2004). Constructing Professional Identities: Montessori teachers' voices and Visions, Scandinavian Journal of Educational Research, 48 (4), 397-410. 
Mallett, J. (2013). Academic achievement outcomes: Montessori and non-Montessori public elementary students. Unpublished Master Thesis. University-Commerce, Texas, USA.

Mcdurham, R (2011). A Comparison of Academic Achievement for Seventh and Eighth Grade Students from Montessori and non-Montessori School Programs. Unpublished Doctoral Dissertation. Tarleton State University, Texas, USA.

Metwally, M. (2015). Montessori entrance and its impact on the achievement of some of the practical life skills of kindergarten children by the point of mothers view. The Scientific Journal, 31 (4), 363-396. (In Arabic).

Ministry of Education (2017). Curriculum document science. Muscat.

Montessori, M. (1995). The Advanced Montessori Method. Bristol, Thoemmas Press.

Montessori, M. (1985). The Secret of Childhood. Hyderabad, Orient Longman limited.

Montessori, M. (1976). From Childhood to Adolescence. New York, Schocken Books.

Murray, A. (2012). Public knowledge of Montessori education. Montessori Life, 24(1), 18-21.

Murray, A. (2008). Public perceptions of Montessori education. Unpublished Doctoral Dissertation, University of Kansas, Ann Arbor, United States.

Onail, W. (2006). Montessori's Philosophy and its way (Mohammad Al - Roussan, Translator). Teacher's Message, 44 (3), 76-81. (In Arabic).

Rice, E. (2017). The impact of Montessori public elementary experiences on high school students. Unpublished Doctoral Dissertation. Capella University, USA.

Sackett, G. (2016) The Scientist in the classroom: The Montessori teacher as scientists, NAMTA Journal, 41 (2), 5-20.

Salazar, M. (2013). The Impact of Montessori Teaching on Academic Achievement of Elementary School Students in a Central Texas School District: A Causal-Comparative Inquiry. Unpublished Doctoral Dissertation. Corpus Christi State University, Texas, USA.

Sullivan-Smith, M. (2008). Montessori and children with autism sensory skill fullness. NAMTA Journal, 33 (2), 68-75.

Walsh, B. and Petty, K. (2007). Frequency of Six Early Childhood Education Approaches: A 10-Year Content Analysis of Early Childhood Education Journal Early Childhood Education Journal, Vol. 34, No. 5, 301- 305. DOI: 10.1007/s10643-0060080-4

Wellington, J. \& Osborne, J (2001). Language and Literacy in Science Education. Buckingham, Open University Press.

Woodsklar, \& Caitlin (2007). Fostering prosocial behaviors in urban elementary schools: daily living skills development for autism children at the Montessori. Unpublished Doctoral Dissertation, University of Pennsylvania, United States. 